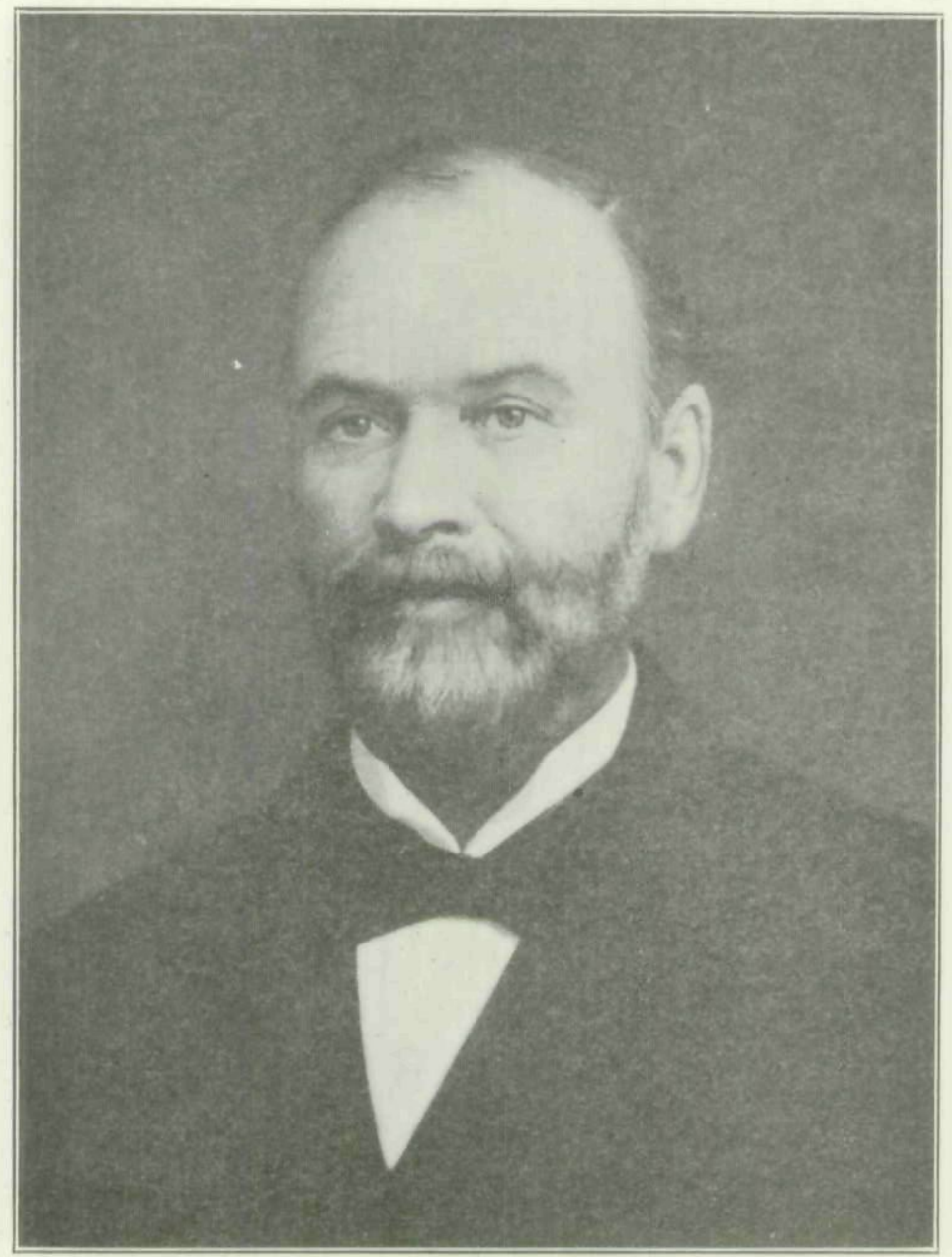

DR. SAMUEL CALVIN

(From a photograph of the oil painting by Charles A. Cumming in Portrait Gallery of Historical Department of Iowa.) 


\section{ADDRESSES MADE ON PRESENTATION OF THE CALVIN MEMORIAL PORTRAIT ${ }^{1}$}

\section{BY DR. THOMAS H. MACBRIDE, CHAIRMAN OF COMMITTEE}

Unable to appear in person for the present program, I have been urged to present myself in some brief address. This I assure you is accomplished not without difficulty. In such attempt one misses so very much, if but in prospect, the happy concourse and sympathy of one's friends, the inspiration of fond, familiar scenes.

However, in the present instance, the task is lightened very much by virtue of the theme, and in the very purpose of our present simple, though unusual ceremony. Sad reminiscence, from fountains however full, may for this hour and presence be repressed, the significance of our whole proceeding so easily, so really a matter of felicitation.

As your committeeman, then, I beg to bring congratulations. This for several reasons. In the first place I venture to declare, as my settled judgment, that in the portrait before us, simply as a picture, we are indeed singularly fortunate. To be sure, in such a matter, each must form opinion for himself, but I expect-for the days to come increasing compliment as the portrait becomes more and more familiar, not to members of the Academy only, but to observers generally.

I think it will be conceded now that our distinguished artist has given his subject careful and conscientious study; he has brought to our service long and patient labor, and a skilful brush. There were serious difficulties. Not only had the artist not known the subject of his effort, he had never even seen him. When we think of this, and reflect that for very form and inspiration, he had in all his work, naught but a few very ordinary photoprints, the result is indeed surprising; not in artistic excellency alone but in accuracy and impressiveness. Our artist should also share the congratulations of this day.

In the second place, we may now rejoice in the Academy's intent and action, manifest so long ago; in the effort of the members and fellows to bring the plans of the Academy to fitting consummation, as in the program of this hour; in this we have, I am sure, a sense of satisfaction to be renewed, we hope, again and again hereafter as the years go by.

1A fine portrait in oil by Charles Atherton Cumming was procured by the Iowa Academy of Science of its eminent former president. Dr. Samuel Calvin, and on April 23, 1920, at its session at Iowa City presented the same to the Historical Department of Iowa, the Curator accepting the portrait on behalf of the Board of Trustees of the Historical Department. The addresses, published in Vol, XXVII of the Proceedings of the Academy, pages 23-32, are here reproduced by courtesy of the Academy.-Editor. 
It is fitting and beautiful for colleagues and fellow-laborers in any field to put in pleasing form some recognition of service rendered, some indication of esteem, some memorial by which the past may, for at least a little time, enrich and cheer the future. Especially is this the case where, as in pure research, service is so often without personal emolument, without thought of gain or even cost, brought forward as a pure gift to humanity, prompted by the simple love of truth, devotion to the beauty, and order, and high significance of the physical world. And if, as now, the unselfish labor has been conspicuous, the vision brilliant, the attainment great, the work accomplished memorable, do we not honor ourselves in thus handing over to the state of Iowa, for the men and women of to-morrow, and yet to-morrow, memorial, such as this? Lo! here some concept of Iowa's most devoted lover; of the master-student of her prairies, her rivers, her forest, her flowers, her rocks, her soils, nor less her wonderful far-fetched history, locked indeed in the very form and structure of soil and stone, but revealed, set forth, not to this Academy alone, decade after decade, but to the young men and women of the commonwealth assembled in scores and hundreds as class succeeded class in the great University; and at last, to the scientific world, in volumes-to-day the grace and pride of the science of the state.

Here is no place for history or biographic details, did one dare indulge it; but may I so far abuse my privilege, and your patience as to tell how fifty years ago, and for many continuous years thereafter I saw a man go forth; in an open wagon, sometimes borrowed, more often hired, sometimes his own, traversing the roadless, bridgeless prairies of northern Iowa; enduring the heat of August suns, chilled by the damps of night, shelterless, tortured by mosquitoes, drenched by wild thunderstorms that made terrible the midnight hours; breakfasting at dawn and toiling until his camp fire burned beneath the evening star. From Lansing to Clarinda, from Dubuque to Mason City, to Winterset, to Ottumwa; athwart the state, across the state, around the state he moved; climbing all rocky heights of nature's carving, pondering the talus of every open quarry, every wall of crumbling rock or sliding shale, wading the creek beds and tracing the banks of larger streams, away from home for weeks together-I knew such a man. In such fashion, and not otherwise, did he win the rich experience and world wisdom presently brought in such overflowing measure to the service of the state of Iowa!

Not for what it has cost, but for what it means, we commit now to the keeping of the public this simple memorial of our colleague. His work is finished, but shall abide long as men live who love their heritage of time. May the work of our artist long endure!

In other worlds and centuries a people, reputed still the wisest, wittiest of earth, not only discovered that "art is long," but likewise also seemed to know that only the skill of the artist does in some mysterious way avail to transmit the soul of things, the thing called inspiration to 
future days and centuries. So they took care of art. They saw to it that men in after times should see what form had Pericles and Plato. Blind Homer nor less Socrates found memorial in marble, if reports are true. Not all were equal to their greatest, but under their greatest every Greek could claim, did claim, and flush with pride that thrills even to this day.

Sometime, perhaps when the social life and institutions of this commonwealth of ours shall have become from river to river more homogeneous, shall crystallize as such things do, when the migration of people shall cease-sometime this our people shall perhaps appreciate their own, sometime mayhap a "temple of fame" shall rise. Shall it be some vast physical structure with marble columns shining, shall it be some noble masterpiece of letters, than brass or marble more enduring, lit by the light of intellect, by passing centuries unworn, undimmed? Whatever, whenever, or wherever the memorial rise, of this let us be sure, upon it the name of our colleague shall appear, among the first have place, and all other commonwealths may rival us if they can!

Nay, my colleagues, there shall still remain, for all whose names in honor shine, memorial nobler, more enduring far. The state, the state itself a living thing, into its fibre have passed the lives of all who thus at the beginning toiled to make it great! The state, sane, noble, intelligent, immortal as we hope, shall inevitably bear in its every character the thought, the purpose high of these its founders, memorial longlasting as the course of time.

\section{BY DR. L. H. PAMMEL ON BEHALF OF THE COMMITTEE}

\section{Mr. President:}

Your committee begs leave to make the following report on the Calvin portrait. At the quarter centennial meeting of the Iowa Academy of Science held in the art room of the Historical Building in Des Moines, April 26 and 27, 1912, a committee was appointed to arrange for a portrait of Doctor Calvin to be presented to the Academy and hung in the art room of the State Historical Department. This committee consisted of Dr. Thomas H. Macbride of the State University, Professor M. F. Arey of the State Teachers College, and Professor L. H. Pammel of Iowa State College. The following letter from the secretary of the Academy explains the scope of the committee:

"A motion was passed that a committee be appointed with power to act, to see that provision be made for the placing of a portrait of Samuel Calvin in the Historical Building. Doctor Macbride, Professor Arey and Doctor Pammel were appointed on this committee,"

After a preliminary meeting of the committee it was left to Doctor Macbride to arrange for the painting of the portrait. Doctor Macbride arranged to have Professor Cumming paint the portrait under his direction, asking numerous old friends of Doctor Calvin to offer 
suggestions. The likeness is a splendid one and reflects credit on the artist and friends who so generously assisted in criticisms.

It fell to the lot of Professor-Arey of the committee to arrange for contributions. These from members of the Academy amounted to $\$ 136.50$. In addition there was paid from the treasury of the Academy the sum of $\$ 123.50$. The remainder of the sum Professor Macbride received from other sources. The committee reported progress from year to year. On March 29, 1916, Professor Macbride wrote the following letter:

"Professor Cumming, the artist, tells me he has the portrait of Professor Calvin in such state of completion that he expects to be able to show it to the Academy at its next meeting in Des Moines."

The portrait, owing to unforseen conditions, was not presented. The committee reported progress and was continued. At the subsequent meetings in Ames in 1917 and Grinnell in 1918 the committee reported progress. At the 1919 meeting in Cedar Falls, Doctor Macbride for the committee stated that the portrait was ready, and to do honor to Doctor Calvin it should be before the Academy an entire session. The task of presenting the portrait of Doctor Calvin to the Academy falls upon the committee.

It is to be regretted that Doctor Macbride, the life-long friend of Doctor Calvin, cannot leave his family in California. The other members of the committee feel that no one could more graciously have presented the portrait than the Nestor of this Academy. His fine spirit is with us. The committee through its chairman has arranged the following program:

"Addresses on behalf of the portrait committee-Professors Macbride, Pammel, and Arey.

"Address on behalf of the Academy moving the acceptance of the portrait-Professor Shimek.

"Address on behalf of the Department of Geology-Professor Thomas.

"Address on behalf of the Iowa Geological Survey-Professor Kay.

"Remarks by the President of the Academy presenting the portrait to the Historical Department of Iowa-President Stephens.

"Response by Edgar R. Harlan, Curator of the Historical Department."

It is fitting that this committee should express its appreciation of the labors of Doctor Calvin as a geologist to the state and nation, an investigator of high order, a teacher of rare ability, a fine citizen and a soldier who helped the cause of freedom during the Civil War.

We honor him not merely as a scholar and teacher in a great university, but we honor him as a citizen of this great commonwealth, and it is proper and fitting that Doctor Calvin's portrait should be a part of the State Historical Collection at Des. Moines to be counted with 
the great men whose portraits adorn the walls of that gallery; to be counted among the men who have made Iowa great in science, religion and statecraft.

The committee having discharged its duties presents this portrait to the Academy.

\section{BY DR. M. F. AREY ON BEHALF OF THE COMMITTEE} Mr. President:

Since Professor Pammel has spoken so satisfactorily in behalf of the committee I will confine myself to a brief characterization of Professor Calvin as a man. My acquaintance with him began about the time at which he became connected with the State University, and fortunately for me I was quite intimately associated with him at times in field work in geology under circumstances that bring out the real nature of the man. I feel therefore that I can say in all sincerity that he was one of God's noblemen, great souled, high minded, a true friend, and efficient in whatever line of work he chose to engage. An incident will illustrate at least two traits of his character. We were engaged in a survey of Winneshiek County which has more geology to the square foot than any other county in the state. It is equally superior in its botany. I knew that for a time he taught botany as well as geology at the University and was still interested in that subject. I was teaching botany as well as geology at the State Normal School at that time and naturally noted much in the vegetation about us that appealed strongly to me. One day as we were passing from one point of investigation to another, some trees rare in Iowa attracted my attention and I spoke to him about them. The only notice he gave to the matter was a remark to the effect that we were now studying the geology of the county and we could not afford to divide our observation or thought with any other subject. The rebuke was given in such a kindly spirit that my feelings could not be said to have been hurt and I proceeded to profit at once by it. His habit evidently was to give himself wholly to the subject in hand, one reason why he succeeded so well in his work.

Among all the capable men who have given themselves in any degree to the pursuit of some phase of Iowa's geology, he stands pre-eminent so that when the subject is mentioned we naturally think of him. The richness of the Pleistocene in Iowa particularly interested him and his work is everywhere to be seen in the differentiation of its five ice sheets, yet his field notes on Taylor County which he had made preparatory to a report of that county, but which he did not live to complete, show that he had found a new problem that strongly appealed to him, namely, the origin and nature of a certain superficial or near superficial phase of the Kansas, later to be known as the gumbotil of Kay. But I promised to be brief that others may have their opportunity to present their tribute of appreciation and respect. 


\section{BY DR. B. SHIMEK ON BEHALF OF THE ACADEMY}

Mr. President:

Rising to move the acceptance of the beautiful gift here presented, I do so with much hesitancy, for two reasons. It was not until a little while ago that I learned just what was expected of me on this occasion, and there has been no time for even the orderly arrangement of the thoughts which should here find expression. Then, too, I fear that the flood of memories which will come all unbidden will make it hard to do justice to the memory of the man whose kindly face looks out upon us from the canvas here presented.

I first learned to know Professor Calvin more than forty years ago, when as a freshman I entered his department as the factotum whose duty it was to furnish field supplies for laboratory work, and during all the years that followed my respect and affection for him grew eon stantly. He was both teacher and friend, and it is difficult to decide in which capacity he gained the stronger hold on the affections of those who were brought in closer contact with him.

Neither time nor the occasion will warrant an extensive account of Professor Calvin's activities. As already noted in the deeply sympathetic letter of his long-time friend and colleague, Doctor Macbride, this is no time for biographical detail. We recall with pride his services as a citizen and soldier; his scientific achievements are a matter of record never to be forgotten; and the memory of his splendid character will remain longest with those who knew him best.

It is nearly fifty years ago that he came to the State University as professor of natural science, and the record of his life is blended with the history of the development of the University and the state. Out of the chair of natural science, or "settee" as he facetiously called it, have grown the strong departments of Geology, Botany, and Zoology in the College of Liberal Arts, and that of Bacteriology in the College of Medicine. He was the organizer of the Iowa Geological Survey and for many years the state geologist, and the record of his work in this connection is too well known to require repetition in this presence.

While we cannot now dwell upon the details of Professor Calvin's life, there are two qualities that stand out as particularly characteristic of him as a teacher, an investigator, and a man, which seem to be especially worthy of note at this time. I refer to his extreme modesty and his sterling honesty. Would that it were possible to burn the memory and the appreciation of the value of these qualities into the minds and the consciousness, especially of the younger generation of scientific workers! A man of strong convictions, yet he approached every problem modestly and with an open mind. There was none of that air of cocksuredness which is sometimes displayed by the narrow specialist, and which is sure to arouse mistrust. No doubt this modest attitude largely prepared the way for the soundness of his conclusions when finally reached. 
His modesty was but a phase of that honesty which was his transcendent quality. He was not only honest in ordinary dealings, but he was honest with himself, and honest in his attitude towards the scientific problems which engrossed his attention. It is this phase of his character which I commend especially to those who are just entering upon a scientific career, for there is no other field in which open-minded honesty is more truly essential.

May this beautiful gift assist in perpetuating the memory of our beloved friend and colleague, and may the example of his noble life inspire us, and those who follow us, to an honest search for truth!

\section{BY DR. A. O. THOMAS ON BEHALF OF THE DEPARTMENT OF GEOLOGY}

Mr. President:

Speaking on behalf of the department founded by Professor Calvin and as one of his pupils during the maturer years of his life, I may be pardoned for pointing out on this impressive occasion that the Geology Department of the University to-day has developed about the ideals of the noble man whose memory we are met to honor and whose portrait is before us. Indeed, his ideals have a profound influence like that of a guardian spirit over the department's activities. Even new instructors who never knew Doctor Calvin confess to a feeling of some benign power that seems to pervade the very atmosphere of old Science Hall. Each member of the staff on occasion doubtless finds himself directed in his teaching methods and departmental policies by the wise standards set by our worthy predecessor. The years we are now passing through are the first stage, it seems to me, in the development of a wholesome tradition, and it is such inspiring traditions as Calvin's ideals that go to make an institution great.

In the Department of Geology to-day the courses offered are largely those developed by Professor Calvin. "Principles of Geology," "General Geology," "Paleontology," "Geology of Iowa" are given in much the way he organized them. That these fundamental courses were broadly planned is evidenced by their flexibility, for today with registration in the department quadrupled since 1911 they to a large degree adequately meet the growing demands. "Principles of Geology" and "General Geology" are courses designed by Calvin for the general student who then as now wants the viewpoint of geology without becoming technically trained. More and more these courses are looked upon as cultural courses and as sources of inspiration; this is as Calvin would have them. Witness some of his favorite themes: "The Great Life Story," "The Glacial Story," "The Face of Iowa," "Geology and Revelation." The substance of these sermons and their spirit, in so far as we can transmit them, are being offered to ever increasing numbers of boys and girls of Iowa illustrated in great part by the very specimens he himself col- 
lected and depicted by illustrations and lantern slides which he made with his own hands. Calvin's collections from all parts of the state and country are the nuclei of present teaching and research materials. It is regrettable that his death cut short his mature plans of writing up and of describing many things he had to leave.

It is only after we are separated by many decades from the work of illustrious men that we begin fully to appreciate the greatness and enduring qualities of their work. Less than a brief decade lies between us and him who laid so well the foundations of geology in Iowa. More and more clearly, however, is there dawning upon us not only the extent to which we are indebted but also the extent to which students yet unborn will be indebted to Calvin's broad conceptions and scholarly interpretations of the geology of the state. The impetus which his rugged honesty, sincerity, and high ideals have engendered will grow ever larger to the end that knowledge may abound and that the truth shall prevail.

Owing to illness Professor Kay was unable to respond on behalf of the Geological Survey. Following the address of Professor Thomas, President Stephens, in a few words put the motion that the Academy accept the portrait. This was carried and the president then introduced Curator Harlan of the Historical Department, who accepted the portrait as follows:

\section{BY EDGAR R. HARLAN, CURATOR}

\section{Mr. President:}

A function of the Historical Department of Iowa is to have at hand the facts and the materials which testify of the merits of Iowa men and events. Merit so proved, which remains permanently apparent throughout all time, is the object of all true effort of the scholarly and is the inspiration of all, unless of the selfish, of every calling. The selection and preservation of the proofs of merit and of attainment being of the duty of the office I for the time occupy, it has been a constant, deep, and firm satisfaction with which I have received the knowledge to-day and in other days of the great place arrived at by Samuel Calvin. The position led to by him, of the science, or branch of science, of which he was the chief Iowa ornament, as by your unanimous voice to-day I am advised, is a place respected through all the realm of scientific thought.

Not many types of evidence bear more sure and satisfactory testimony to the character of a man than the well done portrait. Carlyle has taught us best of that. And this canvas done honestly, considered now by you finally, presented formally to your state, shail carry with it to the place of its perpetual deposit, the stamp of your approval and thereby the indisputable claim to value as a work of history that it is as a work of art.

It is therefore with appropriate satisfaction I am permitted by authority of law to do a small part toward honoring the memory of Samuel Calvin by accepting this delineation of his form approved by you, as I do here now accept. 
Copyright of Annals of Iowa is the property of State of Iowa, by \& through the State Historical Society of Iowa and its content may not be copied or emailed to multiple sites or posted to a listserv without the copyright holder's express written permission. However, users may print, download, or email articles for individual use. 